\title{
Variant Alleles in XRCC1 Arg194Trp and Arg399Gln Polymorphisms Increase Risk of Gastrointestinal Cancer in Sabah, North Borneo
}

\author{
Noor Hanis Abu Halim ${ }^{1}$, Eric Tzyy Jiann Chong ${ }^{1}$, Lucky Poh Wah Goh ${ }^{1}$, Jitt \\ Aun Chuah ${ }^{2}$, Edwin Un Hean See ${ }^{2}$, Kek Heng Chua ${ }^{3}$, Ping-Chin Lee ${ }^{1 *}$
}

\begin{abstract}
Background: The $X R C C 1$ protein facilitates various DNA repair pathways; single-nucleotide polymorphisms (SNPs) in this gene are associated with a risk of gastrointestinal cancer (GIC) with inconsistent results, but no data have been previously reported for the Sabah, North Borneo, population. We accordingly investigated the XRCC1 Arg194Trp and Arg399GIn SNPs in terms of GIC risk in Sabah. Materials and Methods: We performed genotyping for both SNPs for 250 GIC patients and 572 healthy volunteers using a polymerase chain reactionrestriction fragment length polymorphism approach. We validated heterozygosity and homozygosity for both SNPs using direct sequencing. Results: The presence of a variant 194Trp allele in the Arg194Trp SNP was significantly associated with a higher risk of GIC, especially with gastric and colorectal cancers. We additionally found that the variant 399GIn allele in Arg399GIn SNP was associated with a greater risk of developing gastric cancer. Our combined analysis revealed that inheritance of variant alleles in both SNPs increased the GIC risk in Sabah population. Based on our etiological analysis, we found that subjects $\geq 50$ years and males who carrying the variant 194Trp allele, and Bajau subjects carrying the 399GIn allele had a significantly increased risk of GIC. Conclusions: Our findings suggest that inheritance of variant alleles in XRCC1 Arg194Trp and Arg399Gln SNPs may act as biomarkers for the early detection of GIC, especially for gastric and colorectal cancers in the Sabah population.
\end{abstract}

Keywords: Gastrointestinal cancer - Sabah population - XRCC1 polymorphisms

Asian Pac J Cancer Prev, 17 (4), 1925-1931

\section{Introduction}

Cancer is a disease of major impact in world health of which gastrointestinal cancer (GIC) is the most common cancer causing high mortality. According to a report by National Cancer Registry in 2011, a total of 18219 new cancer incidences were diagnosed among Malaysian population in 2007. Colorectal cancer was recorded as second highest percentage of cancer that occurred in Malaysians after breast cancer with the percentage of $12.3 \%$. Among Malay, Chinese and Indian males, colon cancer was the most common followed by other cancers such as lung cancer, prostate cancer and stomach cancer (Zainal Ariffin and Nor Saleha, 2011).

There are 130 known DNA repair genes in human body (Wood et al., 2001). XRCCl gene is the first mammalian gene isolated that affects cellular sensitivity to ionizing radiation (Thompson et al., 1990). Human XRCC1 gene has been proved in correcting the repair defects in the Chinese hamster ovary cell mutant EM9 (Thompson et al., 1990). XRCC1 gene is mapped to human chromosome 19q13.2-13.3 (Mohrenweiser et al., 1989; Thompson et al., 1989) and consists of 17 exons (Wood et al., 2001). It encodes a protein of 633 amino acids (Mohamadynejad and Saadat, 2008) that functions in base excision repair (BER) (Caldecott et al., 1996) and in single-strand breaks (SSB) of damaged bases caused by endogenous and exogenous oxidants (Skjelbred et al., 2006). Proteins that associated to XRCC1 in facilitating the BER and SSB repair processes are polymerase beta, DNA ligase III and poly (ADP-ribose) polymerase (PARP) (Caldecott et al., 1996; Wood et al., 2001; Horton et al., 2008). A study demonstrated by Caldecott et al. revealed that XRCC1 protein formed complex with DNA ligase III, suggested that $X R C C 1$ was required for the normal function of DNA ligase III although it has unknown catalytic activity function (Caldecott et al., 1994).

Even though the XRCC1 does not directly function in repairing the DNA damages, the changes of $X R C C 1$ native sequence and structure due to single nucleotide

${ }^{1}$ Biotechnology Programme, Faculty of Science and Natural Resources, Universiti Malaysia Sabah, ${ }^{2}$ Surgery Department, Queen Elizabeth Hospital, Kota Kinabalu, Sabah, ${ }^{3}$ Department of Biomedical Science, Faculty of Medicine, University of Malaya, Kuala Lumpur, Malaysia*For correspondence:leepc@ums.edu.my 
Noor Hanis Abu Halim et al

polymorphisms (SNPs) in this gene might disrupt the function in repairing the DNA damages. The XRCC1 gene exhibits polymorphic variations including three common SNPs that result in amino acid substitutions in exon 6 (Arg194Trp, base C to T), exon 9 (Arg280His, base G to A) and exon 10 (Arg399Gln, base G to A) (Shen et al., 2000; Stern et al., 2001). Of these, the Arg194Trp and Arg399GIn SNPs have been extensively studied and were associated to GIC risk with inconclusive results, but remain unclear in Sabah (North Borneo) population. Therefore, we accordingly performed this case-control study to examine the association of Arg194Trp and Arg399Gln SNPs in XRCCl gene to GIC risk in the population.

\section{Materials and Methods}

\section{Subjects and DNA extraction}

Peripheral venous blood from a total of $250 \mathrm{GIC}$ patients (134 males and 116 females) from Queen Elizabeth Hospital, Sabah and 572 healthy volunteers (403 males and 169 females) without family cancer history were obtained with consent from January 2010 to December 2014 for this case-control study, regardless the matching of age, gender, and ethnicity. Out of 250 GIC samples, 48 samples were gastric cancer, followed by 175 colorectal, 6 esophageal, 12 liver and 9 pancreas. All subjects were ranged from 15 to 78 years old with mean age \pm S.D. of
$35.64 \pm 0.63$. The clinical data for GIC patients were not available as this pilot study solely focused the association of genetic variation to GIC for early screening of the disease in Sabah population. DNA was extracted from all blood samples using QIAamp DNA Blood Mini Kit (QIAGEN, USA) following the manufacturer's instructions. The principle and methodology of this study were reviewed by Sabah State Health Department, Ministry of Health Malaysia, and the ethical approval for this study was obtained from University Malaya Medical Centre Ethical Board Committee with Ref. 654.1.

\section{XRCC1 genotyping and direct sequencing}

The XRCC1 genotyping for codon 194 and codon 399 polymorphic sites was determined by polymerase chain reaction-restriction fragment length polymorphism (PCRRFLP). DNA samples were amplified using two different primer pairs specific for the two polymorphic regions of $X R C C 1$ gene. Primer sequences were 5'-GCC AGG GCC CCT CCT TCA A-3' (forward) and 5'-TAC CCT CAG ACC CAC GAG T-3' (reverse) for polymorphic site at exon 6 (codon 194) whereas primers used for polymorphic site at exon 10 (codon 399) were 5' -TCC TCC ACC TTG TGC TTT CT-3' (forward) and 5'-AGT AGT CTG CTG GCT CTG GG-3' (reverse). PCR was performed in a 25 $\mu \mathrm{l}$ reaction mixture containing $100 \mathrm{ng}$ of DNA, $0.3 \mu \mathrm{M}$ of each primer, $0.2 \mathrm{mM}$ of dNTP mixtures, $2.0 \mathrm{mM}$ of $\mathrm{MgCl}_{2}$ solution, 1.0 unit of Go Taq® Flexi DNA polymerase

Table 1. Risk Association of XRCC1 Arg194Trp and Arg399GIn SNPs to GIC in Sabah Population

\begin{tabular}{|c|c|c|c|c|}
\hline & Cases, $\mathrm{N}$ & Controls, $\mathrm{N}$ & OR $(95 \% \mathrm{CI})$ & p-value \\
\hline \multicolumn{5}{|l|}{ Arg194Trp SNP } \\
\hline \multicolumn{5}{|l|}{ Allele } \\
\hline 194Arg & 371 & 938 & 1.00 (Reference) & - \\
\hline 194Trp & 129 & 206 & $1.58(1.23-2.03)$ & $<0.001^{*}$ \\
\hline \multicolumn{5}{|l|}{ Genotype } \\
\hline 194Arg/Arg & 129 & 374 & 1.00 (Reference) & - \\
\hline 194Arg/Trp & 113 & 190 & $1.72(1.27-2.34)$ & $<0.001 *$ \\
\hline 194Trp/Trp & 8 & 8 & $2.90(1.07-7.88)$ & $0.037 *$ \\
\hline 194Arg/Trp + 194Trp/Trp & 121 & 198 & $1.77(1.31-2.40)$ & $<0.001 *$ \\
\hline \multicolumn{5}{|l|}{ Arg399Gln SNP } \\
\hline \multicolumn{5}{|l|}{ Allele } \\
\hline 399Arg & 314 & 721 & 1.00 (Reference) & - \\
\hline 399Gln & 186 & 423 & $1.01(0.81-1.26)$ & 0.931 \\
\hline \multicolumn{5}{|l|}{ Genotype } \\
\hline 399Arg/Arg & 96 & 231 & 1.00 (Reference) & - \\
\hline 399Arg/Gln & 122 & 259 & $1.13(0.82-1.56)$ & 0.444 \\
\hline 399Gln/Gln & 32 & 82 & $0.94(0.59-1.51)$ & 0.794 \\
\hline 399Arg/Gln + 399Gln/Gln & 154 & 341 & $1.09(0.80-1.47)$ & 0.593 \\
\hline \multicolumn{5}{|l|}{ Arg194Trp + Arg399Gln SNPs } \\
\hline \multicolumn{5}{|l|}{ Allele } \\
\hline 194Arg + 399Arg & 685 & 1659 & 1.00 (Reference) & - \\
\hline $194 \operatorname{Trp}+399 \mathrm{Gln}$ & 315 & 629 & $1.21(1.03-1.43)$ & $0.020 *$ \\
\hline \multicolumn{5}{|l|}{ Genotype } \\
\hline 194Arg/Arg + 399Arg/Arg & 225 & 605 & 1.00 (Reference) & - \\
\hline 194Arg/Trp + 399Arg/Gln & 235 & 449 & $1.41(1.13-1.75)$ & $0.002 *$ \\
\hline 194Arg/Trp + 399Gln/Gln & 145 & 272 & $1.43(1.11-1.85)$ & $0.005^{*}$ \\
\hline 194Trp/Trp + 399Arg/Gln & 130 & 267 & $1.31(1.01-1.70)$ & $0.042 *$ \\
\hline $194 \mathrm{Trp} / \mathrm{Trp}+399 \mathrm{Gln} / \mathrm{Gln}$ & 40 & 90 & $1.20(0.80-1.79)$ & 0.386 \\
\hline
\end{tabular}

*Statistical significant $(\mathrm{p}<0.05)$; SNP = single nucleotide polymorphism, $\mathrm{N}=$ number of samples, $\mathrm{OR}=\mathrm{odd}$ ratio, $\mathrm{CI}=$ confidence interval, Arg $=$ arginine, $\operatorname{Trp}=$ tryptophan, Gln = glutamine 
(Promega, USA) and $1 \mathrm{X}$ of reaction buffer with conditions set at: $94^{\circ} \mathrm{C}$ for $4 \mathrm{~min}$, followed by 35 cycles of $94^{\circ} \mathrm{C}$ for 30 $\mathrm{s}, 65^{\circ} \mathrm{C}$ for $30 \mathrm{~s}$ and $72^{\circ} \mathrm{C}$ for $45 \mathrm{~s}$, and a final elongation of $7 \mathrm{~min}$ at $72^{\circ} \mathrm{C}$. For RFLP analysis, PCR products were digested at $37^{\circ} \mathrm{C}$ overnight $(\sim 16 \mathrm{hr})$ with 4 units of $P v u \mathrm{II}$ (New England Biolabs, England) and 2 units of NciI (New England Biolabs, England) to distinguish the Arg 194Trp and Arg399Gln SNPs, respectively. The resulted fragments were electrophoresized on $2 \%$ agarose gel stained with ethidium bromide to determine the genotypes of the subjects for both polymorphic sites. Around 5\% of the samples containing all genotypes for both SNPs were repeated for PCR-RFLP and all were matched to their genotype, which further confirmed using direct-sequencing.

\section{Statistical analysis}

The association between XRCC1 polymorphisms to risk of GIC was tested using odd ratio (OR) at $95 \%$ confidence interval $(95 \% \mathrm{CI})$ by taking the common genotype (Arg/Arg for both SNPs) as reference group. The significance of association was determined by Fisher's exact test where the association is considered as statistical significant when the $p$-value is less than 0.05. Significant level for sub-group analysis was accordingly adjusted for the Bonferroni correction. SPSS software V17.0 (SPSS Inc., Chicago, Illinois, USA) was used for all of the data analyses.

\section{Results}

Overall, the variant allele frequencies for 194Trp and $399 \mathrm{Gln}$ in this study were $20.4 \%$ and $37.0 \%$, respectively. In Arg 194Trp SNPrisk association analysis, the presence of 194Trp allele significantly increased the risk to GIC, especially in gastric and colorectal cancers after the Bonferroni correction (Tables 1 and 2). In addition, subjects with variant $399 \mathrm{GIn}$ allele were in higher risk for gastric cancer in Sabah population. The combined analysis revealed that the presence of variant allele in both SNPs had a greater risk towards GIC.

In etiological analysis, subjects with age $\geq 50$ years old and males carrying the variant 194Trp allele had significant higher risk to GIC (Table 3). Besides, Bajau subjects with at least one variant $399 \mathrm{Gln}$ also showed an increase risk to GIC in this study (Table 4).

Table 2. Risk Association of XRCC1 Arg194Trp and Arg399GIn SNPs to Different Types of GIC in Sabah Population

\begin{tabular}{|c|c|c|c|c|}
\hline & Cases, $\mathrm{N}$ & Controls, $\mathrm{N}$ & OR $(95 \% \mathrm{CI})$ & $p$-value \\
\hline \multicolumn{5}{|l|}{ Arg194Trp SNP } \\
\hline \multicolumn{5}{|l|}{ Gastric } \\
\hline 194Arg/Arg & 24 & 374 & 1.00 (Reference) & - \\
\hline 194Arg/Trp & 21 & 190 & $1.72(0.93-3.17)$ & 0.081 \\
\hline $194 \operatorname{Trp} / \operatorname{Trp}$ & 3 & 8 & $5.84(1.46-23.45)$ & $0.013 *$ \\
\hline 194Arg/Trp + 194Trp/Trp & 24 & 198 & $1.89(1.05-3.41)$ & 0.035 \\
\hline \multicolumn{5}{|l|}{ Colorectal } \\
\hline 194Arg/Arg & 90 & 374 & 1.00 (Reference) & - \\
\hline 194Arg/Trp & 81 & 190 & $1.77(1.25-2.51)$ & $0.001 *$ \\
\hline $194 \operatorname{Trp} / \operatorname{Trp}$ & 4 & 8 & $2.08(0.61-7.05)$ & 0.241 \\
\hline 194Arg/Trp + 194Trp/Trp & 85 & 198 & $1.78(1.27-2.51)$ & $0.001 *$ \\
\hline \multicolumn{5}{|l|}{ Others§ } \\
\hline 194Arg/Arg & 15 & 374 & 1.00 (Reference) & - \\
\hline 194Arg/Trp & 11 & 190 & $1.44(0.65-3.20)$ & 0.367 \\
\hline $194 \operatorname{Trp} / \operatorname{Trp}$ & 1 & 8 & $3.12(0.37-26.54)$ & 0.298 \\
\hline 194Arg/Trp + 194Trp/Trp & 12 & 198 & $1.51(0.69-3.29)$ & 0.299 \\
\hline \multicolumn{5}{|l|}{ Arg399Gln SNP } \\
\hline \multicolumn{5}{|l|}{ Gastric } \\
\hline 399Arg/Arg & 9 & 231 & 1.00 (Reference) & - \\
\hline 399Arg/Gln & 29 & 259 & $2.87(1.33-6.20)$ & $0.007 *$ \\
\hline 399Gln/Gln & 10 & 82 & $3.13(1.23-7.97)$ & 0.017 \\
\hline 399Arg/Gln + 399Gln/Gln & 39 & 341 & $2.94(1.40-6.18)$ & $0.005^{*}$ \\
\hline \multicolumn{5}{|l|}{ Colorectal } \\
\hline 399Arg/Arg & 74 & 231 & 1.00 (Reference) & - \\
\hline 399Arg/Gln & 82 & 259 & $0.99(0.69-1.42)$ & 0.949 \\
\hline 399Gln/Gln & 19 & 82 & $0.72(0.41-1.27)$ & 0.26 \\
\hline 399Arg/Gln + 399Gln/Gln & 101 & 341 & $0.92(0.66-1.30)$ & 0.654 \\
\hline \multicolumn{5}{|l|}{ Others $\S$} \\
\hline 399Arg/Arg & 13 & 231 & 1.00 (Reference) & - \\
\hline 399Arg/Gln & 11 & 259 & $0.75(0.33-1.72)$ & 0.502 \\
\hline 399Gln/Gln & 3 & 82 & $0.65(0.18-2.34)$ & 0.51 \\
\hline 399Arg/Gln + 399Gln/Gln & 14 & 341 & $0.73(0.34-1.58)$ & 0.424 \\
\hline
\end{tabular}

*Statistical significant with Bonferroni correction $(\mathrm{p}<0.017)$; $\$$ Including esophageal $(\mathrm{N}=6)$, pancreas $(\mathrm{N}=9)$ and liver $(\mathrm{N}=12)$; $\mathrm{SNP}=$ single nucleotide polymorphism, $\mathrm{N}=$ number of samples, $\mathrm{OR}=$ odd ratio, $\mathrm{CI}=$ confidence interval, $\mathrm{Arg}=\operatorname{arginine}, \operatorname{Trp}=\operatorname{tryptophan}, \mathrm{Gln}=$ glutamine 


\begin{tabular}{|c|c|c|c|c|}
\hline & Cases, $\mathrm{N}$ & Controls, $\mathrm{N}$ & OR $(95 \%$ CI $)$ & p-value \\
\hline \multicolumn{5}{|l|}{ Age } \\
\hline \multicolumn{5}{|l|}{$<50$ years } \\
\hline 194Arg/Arg & 36 & 355 & 1.00 (Reference) & - \\
\hline 194Arg/Trp & 26 & 186 & $1.38(0.81-2.35)$ & 0.239 \\
\hline $194 \operatorname{Trp} / \operatorname{Trp}$ & 3 & 7 & $4.23(1.05-17.06)$ & 0.043 \\
\hline $194 \operatorname{Arg} / \operatorname{Trp}+194 \operatorname{Trp} / \operatorname{Trp}$ & 29 & 193 & $1.48(0.88-2.49)$ & 0.138 \\
\hline \multicolumn{5}{|l|}{$\geq 50$ years } \\
\hline 194Arg/Arg & 93 & 19 & 1.00 (Reference) & - \\
\hline 194Arg/Trp & 87 & 4 & $4.44(1.45-13.58)$ & $0.009 *$ \\
\hline $194 \operatorname{Trp} / \operatorname{Trp}$ & 5 & 1 & $1.02(0.11-9.25)$ & 0.985 \\
\hline $194 \operatorname{Arg} / \operatorname{Trp}+194 \operatorname{Trp} / \operatorname{Trp}$ & 92 & 5 & $3.76(1.35-10.49)$ & $0.012 *$ \\
\hline \multicolumn{5}{|l|}{ Gender } \\
\hline \multicolumn{5}{|l|}{ Male } \\
\hline 194Arg/Arg & 70 & 266 & 1.00 (Reference) & - \\
\hline 194Arg/Trp & 57 & 129 & $1.68(1.12-2.53)$ & $0.013 *$ \\
\hline $194 \operatorname{Trp} / \operatorname{Trp}$ & 7 & 8 & $3.33(1.17-9.48)$ & 0.025 \\
\hline $194 \operatorname{Arg} / \operatorname{Trp}+194 \operatorname{Trp} / \operatorname{Trp}$ & 64 & 137 & $1.78(1.19-2.64)$ & $0.005^{*}$ \\
\hline \multicolumn{5}{|l|}{ Female } \\
\hline 194Arg/Arg & 59 & 108 & 1.00 (Reference) & - \\
\hline $194 \mathrm{Arg} / \operatorname{Trp}$ & 56 & 61 & $1.68(1.04-2.72)$ & 0.035 \\
\hline $194 \operatorname{Trp} / \operatorname{Trp}$ & 1 & 0 & - & - \\
\hline $194 \operatorname{Arg} / \operatorname{Trp}+194 \operatorname{Trp} / \operatorname{Trp}$ & 57 & 61 & $1.71(1.06-2.77)$ & 0.029 \\
\hline \multicolumn{5}{|l|}{ Ethnicity } \\
\hline \multicolumn{5}{|l|}{ Bajau } \\
\hline 194Arg/Arg & 22 & 44 & 1.00 (Reference) & - \\
\hline $194 \mathrm{Arg} / \mathrm{Trp}$ & 14 & 20 & $1.40(0.60-3.29)$ & 0.44 \\
\hline $194 \operatorname{Trp} / \operatorname{Trp}$ & 1 & 2 & $1.00(0.09-11.64)$ & 1 \\
\hline $194 \operatorname{Arg} / \operatorname{Trp}+194 \operatorname{Trp} / \operatorname{Trp}$ & 15 & 22 & $1.36(0.59-3.13)$ & 0.465 \\
\hline \multicolumn{5}{|l|}{ Chinese } \\
\hline 194Arg/Arg & 27 & 41 & 1.00 (Reference) & - \\
\hline $194 \mathrm{Arg} / \operatorname{Trp}$ & 39 & 33 & $1.79(0.92-3.51)$ & 0.088 \\
\hline $194 \operatorname{Trp} / \operatorname{Trp}$ & 3 & 0 & - & - \\
\hline $194 \operatorname{Arg} / \operatorname{Trp}+194 \operatorname{Trp} / \operatorname{Trp}$ & 42 & 33 & $1.93(0.99-3.76)$ & 0.053 \\
\hline \multicolumn{5}{|l|}{ KadazanDusun } \\
\hline 194Arg/Arg & 46 & 163 & 1.00 (Reference) & - \\
\hline 194Arg/Trp & 28 & 63 & $1.57(0.91-2.74)$ & 0.107 \\
\hline $194 \operatorname{Trp} / \operatorname{Trp}$ & 2 & 2 & $3.54(0.49-25.85)$ & 0.212 \\
\hline $194 \operatorname{Arg} / \operatorname{Trp}+194 \operatorname{Trp} / \operatorname{Trp}$ & 30 & 65 & $1.64(0.95-2.81)$ & 0.076 \\
\hline \multicolumn{5}{|l|}{ Others ${ }^{\S}$} \\
\hline 194Arg/Arg & 34 & 126 & 1.00 (Reference) & - \\
\hline $194 \mathrm{Arg} / \mathrm{Trp}$ & 32 & 74 & $1.60(0.91-2.81)$ & 0.1 \\
\hline $194 \operatorname{Trp} / \operatorname{Trp}$ & 2 & 4 & $1.85(0.33-10.55)$ & 0.487 \\
\hline 194Arg/Trp + 194Trp/Trp & 34 & 78 & $1.62(0.93-2.81)$ & 0.089 \\
\hline
\end{tabular}

*Statistical significant with Bonferroni correction $(\mathrm{p}<0.025)$; §Including other indigenous groups (i.e. Rungus, Murut, etc.) and cross-married ethnicities in Sabah; $\mathrm{N}=$ number of samples, $\mathrm{OR}=$ odd ratio, $\mathrm{CI}=$ confidence interval, $\mathrm{Arg}=\operatorname{arginine}$, Trp = tryptophan

\section{Discussion}

This study investigated whether the Arg194Trp and Arg399Gln polymorphic sites in XRCCl gene could have an impact on GIC risk in Sabah population. XRCC1 Arg194Trp is located in the linker region that separates DNA polymerase- $\beta$ interacting domain from the PARP interacting domain (Kubota et al., 1996) whereas XRCC1 Arg399GIn is located on the COOH-terminal side of the PARP interacting domain within the BRCA1 C-terminal domain (Masson et al., 1998; Zhang et al., 1998) that are thought to mediate several protein-protein interactions (Masson et al., 1998). Amino acid substitutions that occur at these important regions might cause DNA repair deficiency in human (Lunn et al., 1999) as it was previously reported in hamster due to functionality disrupted of XRCC1 gene (Shen et al., 1998).

Allele frequency of the variant 194Trp in Arg194Trp SNP was higher in GIC patients (25.8\%) when compared to controls $(18.0 \%)$, suggesting that this allele might be an increase risk factor for GIC in Sabah population. Frequency of 194Trp allele in our study was higher than GIC cases reported in Egypt and Mexico (Abdel-Rahman et al., 2000; Muñiz-Mendoza et al., 2012) but was lower than those reported in Eastern Asia including Han Chinese, Japanese and Korean populations (Hong et al., 2005; Wen 
Table 4. Association of Age, Gender and Ethnicity in XRCC1 Arg399GIn SNP to GIC in Sabah Population

\begin{tabular}{|c|c|c|c|c|}
\hline & Cases, $\mathrm{N}$ & Controls, $\mathrm{N}$ & OR $(95 \% \mathrm{CI})$ & p-value \\
\hline \multicolumn{5}{|l|}{ Age } \\
\hline \multicolumn{5}{|l|}{$<50$ years } \\
\hline 399Arg/Arg & 31 & 222 & 1.00 (Reference) & - \\
\hline 399Arg/Gln & 27 & 248 & $0.78(0.45-1.35)$ & 0.372 \\
\hline 399Gln/Gln & 7 & 78 & $0.64(0.27-1.52)$ & 0.314 \\
\hline 399Arg/Gln + 399Gln/Gln & 34 & 326 & $0.75(0.45-1.25)$ & 0.267 \\
\hline \multicolumn{5}{|l|}{$\geq 50$ years } \\
\hline 399Arg/Arg & 65 & 9 & 1.00 (Reference) & - \\
\hline 399Arg/Gln & 95 & 11 & $1.20(0.47-3.05)$ & 0.708 \\
\hline 399Gln/Gln & 25 & 4 & $0.87(0.24-3.07)$ & 0.823 \\
\hline 399Arg/Gln + 399Gln/Gln & 120 & 15 & $1.11(0.46-2.67)$ & 0.82 \\
\hline \multicolumn{5}{|l|}{ Gender } \\
\hline \multicolumn{5}{|l|}{ Male } \\
\hline 399Arg/Arg & 51 & 171 & 1.00 (Reference) & - \\
\hline 399Arg/Gln & 68 & 178 & $1.28(0.84-1.95)$ & 0.247 \\
\hline 399Gln/Gln & 15 & 54 & $0.93(0.49-1.79)$ & 0.831 \\
\hline 399Arg/Gln + 399Gln/Gln & 83 & 232 & $1.20(0.80-1.79)$ & 0.374 \\
\hline \multicolumn{5}{|l|}{ Female } \\
\hline 399Arg/Arg & 45 & 60 & 1.00 (Reference) & - \\
\hline 399Arg/Gln & 54 & 81 & $0.89(0.53-1.49)$ & 0.656 \\
\hline 399Gln/Gln & 17 & 28 & $0.81(0.40-1.66)$ & 0.563 \\
\hline 399Arg/Gln + 399Gln/Gln & 71 & 109 & $0.87(0.53-1.42)$ & 0.572 \\
\hline \multicolumn{5}{|l|}{ Ethnicity } \\
\hline \multicolumn{5}{|l|}{ Bajau } \\
\hline 399Arg/Arg & 13 & 43 & 1.00 (Reference) & - \\
\hline 399Arg/Gln & 21 & 14 & $4.96(1.98-12.42)$ & $0.001 *$ \\
\hline 399Gln/Gln & 3 & 9 & $1.10(0.26-4.68)$ & 0.895 \\
\hline 399Arg/Gln + 399Gln/Gln & 24 & 23 & $3.45(1.48-8.03)$ & $0.004 *$ \\
\hline \multicolumn{5}{|l|}{ Chinese } \\
\hline 399Arg/Arg & 40 & 41 & 1.00 (Reference) & - \\
\hline 399Arg/Gln & 25 & 26 & $0.99(0.49-1.99)$ & 0.968 \\
\hline 399Gln/Gln & 4 & 7 & $0.59(0.16-2.16)$ & 0.421 \\
\hline 399Arg/Gln + 399Gln/Gln & 29 & 33 & $0.90(0.46-1.75)$ & 0.757 \\
\hline \multicolumn{5}{|l|}{ KadazanDusun } \\
\hline 399Arg/Arg & 17 & 74 & 1.00 (Reference) & - \\
\hline 399Arg/Gln & 40 & 113 & $1.54(0.81-2.92)$ & 0.185 \\
\hline 399Gln/Gln & 19 & 41 & $2.02(0.95-4.30)$ & 0.069 \\
\hline 399Arg/Gln + 399Gln/Gln & 59 & 154 & $1.67(0.91-3.06)$ & 0.098 \\
\hline \multicolumn{5}{|l|}{ Others ${ }^{\S}$} \\
\hline 399Arg/Arg & 26 & 73 & 1.00 (Reference) & - \\
\hline 399Arg/Gln & 36 & 106 & $0.95(0.53-1.71)$ & 0.874 \\
\hline 399Gln/Gln & 6 & 25 & $0.67(0.25-1.83)$ & 0.438 \\
\hline 399Arg/Gln + 399Gln/Gln & 42 & 131 & $0.90(0.51-1.59)$ & 0.716 \\
\hline
\end{tabular}

*Statistical significant with Bonferroni correction $(\mathrm{p}<0.013)$; 'Including other indigenous groups (i.e. Rungus, Murut, etc.) and cross-married ethnicities in Sabah; $\mathrm{N}=$ number of samples, $\mathrm{OR}=$ odd ratio, $\mathrm{CI}=$ confidence interval, $\mathrm{Arg}=$ arginine, $\mathrm{Gln}=$ glutamine

et al., 2012; Yin et al., 2012; Gao et al., 2014; Huang et al., 2015; Yun et al., 2015). In Arg399GIn SNP analysis, the variant 399Gln allele frequency was slightly higher in GIC $(37.2 \%)$ when compared to controls $(37.0 \%)$ in the present study. Interestingly, the $399 \mathrm{GIn}$ allele frequency was found higher when compared to those GIC cases reported in Egyptian, Han Chinese, Japanese, Korean and Western Mexican populations (Abdel-Rahman et al., 2000; Hong et al., 2005; Muñiz-Mendoza et al., 2012; Yin et al., 2012; Gao et al., 2014; Yun et al., 2015) but was lower to Thai population (Putthanachote et al., 2015). Difference in distribution of variant allele in both SNPs among studies indicates that there is a need to clarify the allele distribution of different populations for more precise risk estimation of XRCC1 SNPs towards GIC.

Our study revealed that the presence of variant $194 \operatorname{Trp}$ allele in XRCC1 Arg194Trp SNP was associated with an increase risk of GIC in Sabah population, especially in gastric and colorectal cancers. In agreement with our results, association between the inheritance of 194Trp allele and risk of GIC cancer was also reported in Egyptian, Kashmiri and Korean populations where this allele increased the risk of colorectal cancer (AbdelRahman et al., 2000; Hong et al., 2005; Nissar et al., 2015). A recent meta-analysis also claimed that the presence of the 194Trp allele had a higher risk for gastric 
cancer in Asian (Zhao et al., 2014). However, the variant 194Trp/Trp genotype was previously been reported as a protective factor for gastric cancer in Chinese (Shen et al., 2000) and pancreatic cancer in US Caucasians (Jiao et al., 2006). In addition to GIC, XRCC1 Arg194Trp SNP was also associated with other cancers such as breast, lung, glioma and thyroid (Chen et al., 2002; Pachouri et al., 2007; Rodrigues et al., 2011; Du et al., 2013; Feng et al., 2014; Xu et al., 2014). This suggests that 194Trp allele in $X R C C 1$ gene might be a core factor in altering the DNA repair mechanism and leads to several cancers development, and further investigation will be needed for this aspect.

Besides, the presence of $399 \mathrm{Gln}$ allele in the Arg399GIn SNP was significantly associated with higher risk of gastric cancer. Previous studies reported that the heterozygous (399Arg/Gln) and variant (399Gln/Gln) genotypes of this SNP were significant risk factor for GIC in different populations including in Han Chinese for liver, gastric and colorectal cancers (Shen et al., 2000; Pan et al., 2011; Li et al., 2012; Zhao et al., 2012), US Caucasian for pancreatic cancer (Jiao et al., 2006) as well as Egyptian, Kashmiri, Korean and Japanese for colorectal cancer (Abdel-Rahman et al., 2000; Hong et al., 2005; Yin et al., 2012; Nissar et al., 2013). A recent meta-analysis also suggested that subjects with at least one 399Gln allele elevated the risk of hepatocellular cancer in Asian population (Liu et al., 2013) but other claimed that no direct association of this allele to colorectal cancer (Qin et al., 2015). Nevertheless, a study in Han Chinese revealed that these genotypes were reduced risk factor for esophageal squamous-cell carcinoma (ESCC) in the population (Xing et al., 2002). The inconclusive findings of this SNP towards different types of GIC should be further validated for different populations with larger sample size.

Since SNPs within the same gene may interfere with each other in their molecular mechanism, we investigated the combined effect of both SNPs to risk of GIC in this study. Our results suggested that subjects carrying both variant alleles significantly increased the risk of GIC in Sabah population. This finding was in contrast to a study conducted in Han Chinese where individuals with 194Arg/Trp + 399Gln/Gln and 194Trp/Trp + 399Gln/ Gln genotypes had a reduced risk to colorectal cancer, but higher risk towards colorectal cancer was observed in individuals with high alcohol intake (Gao et al., 2014), suggesting that lifestyle and environmental factors could alter the risk towards different type of cancers for subjects with similar heredity. As one of the limitations in this study was no description regarding lifestyle of the subjects, therefore interaction between SNPs and lifestyle should be included in future study for better understanding and estimation on risk association of SNPs to GIC.

Sabah is a multi-ethnicities state in Malaysia with majority of Bajau, Chinese and KadazanDusun. More than $30 \%$ of our total samples were categorized as others because cross-ethnic married has commonly being practiced in Sabah population. Etiological analysis including all ethnics in Sabah population showed that subjects who were $\geq 50$ years and males carrying the variant 194Trp allele had an increase risk for GIC. When the subjects were stratified to ethnicity, Bajau subjects with 399 Gln allele were at higher risk for GIC. This is the first significant study to report the association between XRCC1 SNPs and etiological factors to GIC risk among Sabah population. Since the molecular mechanism between $X R C C 1$ gene polymorphisms and etiological factors in GIC development is still unknown, this aspect should be addressed in the future for more effectual in GIC prevention especially in states or countries with multiracial populations such as in Sabah population.

In summary, our study suggested the presence of 194Trp allele significantly exposed higher risk to GIC, especially in gastric and colorectal cancers. Besides, variant 399Gln allele also revealed greater risk for gastric cancer. The presence of variant allele in both SNPs could be act as biomarkers for early detection of GIC among Sabah population as they were significantly increased the risk of the disease. This study also pinpointed a significant gene-etiological interaction towards GIC risk. Future study should include the lifestyle of the subjects and gene-environmental interaction with larger sample size to provide a greater view for GIC risk estimation in different ethnicities among Sabah population.

\section{Acknowledgements}

We would like to thank all staffs at Blood Bank Unit, Hospital of Women and Children, Kota Kinabalu, Sabah for their assistance in this study. This study is supported by Science Fund grant project no. 02-01-10-SF0080 from Ministry of Science, Technology and Innovation (MOSTI), Malaysia.

\section{References}

Abdel-Rahman SZ, Soliman AS, Bondy ML, et al (2000). Inheritance of the 194Trp and the 399Gln variant alleles of the DNA repair gene $X R C C 1$ are associated with increased risk of early-onset colorectal carcinoma in Egypt. Cancer Lett, 159, 79-86.

Caldecott KW, Aoufouchi S, Johnson P, Shall S (1996). XRCC1 polypeptide interacts with DNA polymerase beta and possibly poly (ADP-ribose) polymerase, and DNA ligase III is a novel molecular 'nick-sensor' in vitro. Nucleic Acids Res, 24, 4387-94.

Caldecott KW, McKeown CK, Tucker JD, Ljungguist S, Thompson LH (1994). An interaction between the mammalian DNA repair protein $X R C C 1$ and DNA ligase III. Mol Cell Biol, 14, 68-76.

Chen S, Tang D, Xue K, et al (2002). DNA repair gene XRCC1 and XPD polymorphisms and risk of lung cancer in a Chinese population. Carcinogenesis, 23, 1321-5.

Du Y, Han LY, Li DD, et al (2013). Associations between XRCC1 Arg399Gln, Arg 194Trp, and Arg280His polymorphisms and risk of differentiated thyroid carcinoma: a meta-analysis. Asian Pac J Cancer Prev, 14, 5483-7.

Feng YZ, Liu YL, He XF, et al (2014). Association between the XRCC1 Arg194Trp polymorphism and risk of cancer: evidence from 201 case-control studies. Tumor Biol, 35, 10677-97.

Gao CM, Ding JH, Li SP, et al (2014). Polymorphisms in XRCC1 gene, alcohol drinking, and risk of colorectal cancer: a case- 
Variant Alleles in XRCC1 Arg194Trp and Arg399Gln Increase Risk of Gastrointestinal Cancer in Sabah, North Borneo

control study in Jiangsu Province of China. Asian Pac $J$ Cancer Prev, 14, 6613-8.

Hong YC, Lee KH, Kim WC, et al (2005). Polymorphisms of $X R C C 1$ gene, alcohol consumption and colorectal cancer. Int J Cancer, 116, 428-32.

Horton JK, Watson M, Stefanick DF, et al (2008). XRCC1 and DNA polymerase $\beta$ in cellular protection against cytotoxic DNA single strand breaks. Cell Res, 18, 48-63.

Huang Y, Li XH, He J, et al (2015). Genetic polymorphisms in $X R C C 1$ genes and colorectal cancer susceptibility. World $J$ Surg Oncol, 13, 244.

Jiao L, Bondy ML, Hassan MM, et al (2006). Selected polymorphisms of DNA repair genes and risk of pancreatic cancer. Cancer Detect Prev, 30, 284-91.

Kubota Y, Nash RA, Klungland A, et al (1996). Reconstitution of DNA base excision- repair with purified human proteins: interaction between DNA polymerase $\beta$ and the XRCC1 protein. EMBO J, 15, 6662-70.

Li QW, Lu CR, Ye M, Xiao WH, Liang J (2012). Evaluation of DNA repair gene $X R C C 1$ polymorphism in prediction and prognosis of hepatocellular carcinoma risk. Asian Pac $J$ Cancer Prev, 13, 191-4.

Liu Y, He XF, Lu YT, et al (2013). Association between the XRCC1 Arg399Gln polymorphism and risk of cancer: evidence from 297 case-control studies. PLoS ONE, 8, 78071.

Lunn RM, Langlois RG, Hsieh LL, Thompson CL, Bell DA (1999). XRCC1 polymorphisms: effects on aflatoxin B1DNA adducts and glycophorin A variant frequency. Cancer Res, 59, 2557-61.

Masson M, Niedergang C, Schreiber V, et al (1998). XRCC1 is specifically associated with poly (ADP-ribose) polymerase and negatively regulates its activity following DNA damage. Mol Cell Biol, 18, 3563-71.

Mohamadynejad P, Saadat M (2008). Genetic polymorphisms of XRCC1 (at codons 194 and 399) in Shiraz population (Fars province, southern Iran). Mol Biol Rep, 35, 669-72.

Mohrenweiser HW, Carrano AV, Fertitta A, et al (1989). Refined mapping of the three DNA repair genes, ERCC1, ERCC2, and XRCC1, on human chromosome 19. Cytogenet Cell Genet, 52, 11-4.

Muñiz-Mendoza R, Ayala-Madrigal ML, Partida-Pérez M, et al (2012). MLH1 and XRCC1 polymorphisms in Mexican patients with colorectal cancer. Genet Mol Res, 11, 2315-20.

Nissar S, Lone TA, Banday MZ, et al (2013). Arg399Gln polymorphism of $X R C C 1$ gene and risk of colorectal cancer in Kashmir: a case control study. Oncol Lett, 5, 959-63.

Nissar S, Sameer AS, Rasool R, Chowdri NA, Rashid F (2015). Polymorphism of the DNA repair gene XRCC1 (Arg 194Trp) and its role in colorectal cancer in Kashmiri population: a case control study. Asian Pac J Cancer Prev, 16, 6385-90.

Pachouri SS, Sobti RC, Kaur P, Singh J (2007). Contrasting impact of DNA repair gene XRCC1 polymorphism Arg399Gln and Arg194Trp on the risk of lung cancer in the north-Indian population. DNA Cell Biol, 26, 186-91.

Pan HZ, Liang J, Yu Z, et al (2011). Polymorphism of DNA repair gene $X R C C 1$ and hepatocellular carcinoma risk in Chinese population. Asian Pac J Cancer Prev, 12, 2947-50.

Putthanachote N, Promthet S, Suwanrungruan K, et al (2015). XRCC1 gene polymorphism, clinicopathological characteristics and stomach cancer survival in Thailand. Asian Pac J Cancer Prev, 16, 6111-6.

Qin CJ, Xu KW, Chen ZH, et al (2015). XRCC1 R399Q polymorphism and colorectal cancer risk in the Chinese Han population: a meta-analysis. Tumor Biol, 36, 461-6.

Rodrigues MS, Machado CA, Pagnoncelli D, et al (2011).TP53 and $\mathrm{XRCC1}$ polymorphisms and breast cancer prognosis: a case-control study. Clinics, 66, 1097-100.

Shen H, Xu Y, Qian Y, et al (2000). Polymorphisms of the DNA repair gene $X R C C 1$ and risk of gastric cancer in a Chinese population. Int J Cancer, 88, 601-6.

Shen MR, Jones IM, Mohrenweiser H (1998). Nonconservative amino acid substitution variants exist at polymorphic frequency in DNA repair genes in healthy humans. Cancer Res, 58, 604-8.

Skjelbred CF, Saebo M, Wallin H, et al (2006). Polymorphisms of the $X R C C 1, X R C C 3$ and $X P D$ genes and risk of colorectal adenoma and carcinoma, in a Norwegian cohort: a case control study. BMC Cancer, $6,67$.

Stern MC, Umbach DM, van Gils CH, Lunn RM, Taylor JA (2001). DNA repair gene $X R C C 1$ polymorphisms, smoking and bladder cancer risk. Cancer Epidemiol Biomarkers Prev, 10, 125-31.

Thompson LH, Bachinski LL, Stallings RL, et al (1989). Complementary of repair gene mutations on the hemizygous chromosome 9 in CHO: a third repair gene on human chromosome 19. Genomics, 5, 670-9.

Thompson LH, Brookman KW, Jones NJ, Allen SA, Carrano AV (1990). Molecular cloning of the human XRCC1 gene, which corrects defective DNA strand break repair and sister chromatid exchange. Mol Cell Biol, 10, 6160-71.

Wen YY, Pan XF, Loh M, et al (2012). ADPRT Val762Ala and XRCC1 Arg194Trp polymorphisms and risk of gastric cancer in Sichuan China. Asian Pac J Cancer Prev, 13, 2139-44.

Wood RD, Mitchell M, Sgouros J, Lindahl T (2001). Human DNA repair genes. Science, 291, 1284-9.

Xing D, Qi J, Miao X, et al (2002). Polymorphisms of DNA repair genes $X R C C 1$ and $X P D$ and their associations with risk of esophageal squamous cell carcinoma in a Chinese population. Int J Cancer, 100, 600-5.

Xu C, Chen P, Liu W, Gu AH, Wang XR (2014). Association between the XRCC1 Arg194Trp polymorphism and glioma risk: an updated meta-analysis. Asian Pac J Cancer Prev, 15, 7419-24.

Yin G, Morita M, Ohnaka K, et al (2012). Genetic polymorphisms of XRCC1, alcohol consumption, and the risk of colorectal cancer in Japan. $J$ Epidemiol, 22, 64-71.

Yun YX, Dai LP, Wang P, et al (2015). Association of polymorphisms in $\mathrm{X}$-ray repair cross complementing 1 gene and risk of esophageal squamous cell carcinoma in Chinese population. BioMed Res Int, 2015, 509215.

Zainal Ariffin O, Nor Saleha IT (2011). National Cancer Registry Report: Malaysia Cancer Statistics - Data and Figure 2007. Ministry of Health Malaysia, Kuala Lumpur, 23-33.

Zhang X, Morera S, Bates PA, et al (1998). Structure of an $X R C C 1$ BRCT domain: a new protein-protein interaction module. EMBO J, 17, 6404-11.

Zhao DY, Cheng L, Yu J, Shen H (2014). XRCC1 genetic polymorohism Arg399Gln, Arg194Trp, Arg280His and gastric cancer risk: an evidence based decision. Cancer Biomark, 14, 449-56.

Zhao Y, Deng X, Wang Z, Wang Q, Liu Y (2012). Genetic polymorphisms of DNA repair genes $X R C C 1$ and $X R C C 3$ and risk of colorectal cancer in Chinese population. Asian Pac J Cancer Prev, 13, 665-9. 